This chapter explores how racial and ethnic identity

develops and how a sensitivity to this process can improve

adult education.

\title{
Racial and Ethnic Identity and Development
}

\author{
Alicia Fedelina Chávez, Florence Guido-DiBrito
}

Racial and ethnic identity are critical parts of the overall framework of individual and collective identity. For some especially visible and legally defined minority populations in the United States, racial and ethnic identity are manifested in very conscious ways. This manifestation is triggered most often by two conflicting social and cultural influences. First, deep conscious immersion into cultural traditions and values through religious, familial, neighborhood, and educational communities instills a positive sense of ethnic identity and confidence. Second, and in contrast, individuals often must filter ethnic identity through negative treatment and media messages received from others because of their race and ethnicity.

These messages make it clear that people with minority status have a different ethnic make-up and one that is less than desirable within mainstream society. Others, especially white Americans, manifest ethnic and racial identity in mostly unconscious ways through their behaviors, values, beliefs, and assumptions. For them, ethnicity is usually invisible and unconscious because societal norms have been constructed around their racial, ethnic, and cultural frameworks, values, and priorities and then referred to as "standard American culture" rather than as "ethnic identity." This unconscious ethnic identity manifests itself in daily behaviors, attitudes, and ways of doing things. Unlike many minority cultures, there is little conscious instilling of specific ethnic identity through white communities, nor is differential ethnic treatment often identified in the media of white cultures. As we discuss throughout this chapter, everyone benefits from the development of a conscious ethnic identity and benefits as well when multicultural frameworks are used in their learning environments. 
The purpose of this chapter is to review pertinent racial and ethnic identity literature to better understand how it informs adult learning. First, we define racial and ethnic identity and stress the importance of examining these concepts from a multidimensional frame. Next, we discuss racial and ethnic identity through developmental and descriptive lenses and highlight the strengths and limitations of the models presented. Finally, we discuss implications and share strategies for working with adult learners.

\section{Definitions of Racial and Ethnic Identity}

The constructs of race and ethnicity in the United States are complex and difficult to define and frame. Researchers are not consistent in their meaning, which makes these concepts particularly challenging to grasp. To add to the confusion, racial and ethnic identity "transcends traditional categories and has become a major topic in psychology, literature, theology, philosophy, and many other disciplines" (Harris, 1995, p. 2).

The concept of racial identity, in particular, has been misunderstood and contested. Some meanings are derived from its biological dimension (Spickard, 1992) and others from its social dimension (Helms, 1995; Spickard, 1992). As a biological category, race is derived from an individual's "physical features, gene pools and character qualities" (Spickard, 1992, p. 14). Using these features as distinguishing characteristics, Europeans grouped people hierarchically by physical ability and moral quality, with Caucasians as the pinnacle, followed by Asians and Native Americans, and Africans last on the racial ladder (Spickard, 1992). However, looking beyond these characteristics, there are more similarities than differences between racial groups and more differences than similarities within these groups (Littlefield, Lieberman, and Reynolds, 1982).

Today, literary and theoretical manifestations of racial identity are discussed not in biological terms (which may imply a racist perspective) but as a social construction, which "refers to a sense of group or collective identity based on one's perception that he or she shares a common heritage with a particular racial group" (Helms, 1993, p. 3). Racial identity seems most often, however, to be a frame in which individuals categorize others, often based on skin color (O'Hearn, 1998). The use of skin color is one of many labeling tools that allow individuals and groups to distance themselves from those they consider different from themselves (Chávez, Guido-DiBrito, and Mallory, 1996). Racial identity is a surface-level manifestation based on what we look like yet has deep implications in how we are treated.

Ethnic identity is often considered a social construct as well (Waters, 1990). It is viewed as an individual's identification with "a segment of a larger society whose members are thought, by themselves or others, to have a common origin and share segments of a common culture and who, in addition, participate in shared activities in which the common origin and culture are significant ingredients" (Yinger, 1976, p. 200). Ethnic identity 
seems most often to be a frame in which individuals identify consciously or unconsciously with those with whom they feel a common bond because of similar traditions, behaviors, values, and beliefs (Ott, 1989). These points of connection allow individuals to make sense of the world around them and to find pride in who they are. If, however, positive ethnic group messages and support are not apparent or available to counteract negative public messages, a particular individual is likely to feel shame or disconnection toward their own ethnic identity. Ethnic identity development consists of an individual's movement toward a highly conscious identification with their own cultural values, behaviors, beliefs, and traditions. Ethnic and racial identity models provide a theoretical structure for understanding individuals' negotiation of their own and other cultures.

\section{Models of Ethnic and Racial Identity Development}

Models and theories of racial and ethnic identity development have rapidly multiplied in the last two decades as the "melting pot" framework has given way to acknowledgment of a racially and ethnically diverse U.S. population. Most identity development models and theories trace their roots to either the psychosocial research of Erik Erikson (1959/1980), the identity formation studies of Marcia (1980), or the cognitive structural work of Jean Piaget (1952). Curiously, all identity models focus on the psychosocial process of defining the self; some also acknowledge the cognitive complexity of the self-definition process (Evans, Forney, and Guido-DiBrito, 1998; Helms, 1993). The traditional models in both categories (psychosocial and cognitive structural) are stage models in which growth occurs linearly in a stepwise progression, whereas contemporary models describe racial and ethnic identity as a process that occurs over a lifetime.

Racial Identity Development. These models were originally developed primarily for African Americans to understand the black experience in the United States. Cross $(1971,1995)$ developed one of the first and most prevalent models of psychological nigrescence, a "resocialization experience" (1995, p. 97), in which a healthy black progresses from a non-Afrocentric to an Afrocentric to a multicultural identity. During this transformation, the individual ideally moves from a complete unawareness of race through embracing black culture exclusively toward a commitment to many cultures and addressing the concerns of all oppressed groups. Cross's model is helpful in outlining racial identity as a dynamic progression, as influenced by those in a particular individual's ethnic group as well as those outside it, and in acknowledging ethnocentric and multicultural frames. Grounded in the context of the civil rights movement, Cross's early work is problematic in that he starts from the premise that before blacks experience identity, they are first unaware of their race and the race of others.

Parham (1989) describes cycles of racial identity development as a lifelong, continuously changing process for blacks. He theorizes that individuals 
move through angry feelings about whites and develop a positive black frame of reference. Ideally this leads to a realistic perception of one's racial identity and to bicultural success. Parham relates black identity directly to white people in a way that moves individual black identity from the unconscious to the conscious. This model clearly delineates that when blacks brush up against white culture and negative differential treatment by others, feelings of difference are triggered and subsequently a consciousness of racial identity is as well.

What is helpful in Parham's model is a sense of progression. In addition, the model outlines a movement from an unconscious to a conscious racial identity. Problematic in Parham's model is his identification of unavoidable exposure to racial difference as the primary trigger for the development of racial identity. Rather, we believe the primary trigger for individual racial identity is immersion in one's own racial group and transference of a racial self through that immersion.

Helms (1993, 1994, 1995) developed one of the first white racial identity models. Her model presupposes the existence of white superiority and individual, cultural, and institutional racism. Finding stages to be a limiting concept, primarily because individuals can be in more than one stage at a time, Helms instead refers to the status of white racial identity. Her first three statuses outline how a white individual progresses away from a racist frame before moving to the next three statuses where they discover a nonracist white identity. Helms's model is helpful in outlining interracial exposure as a powerful trigger for the development of racial identity. Problematic in this model is Helms's confusion of an individual's development toward a nonracist frame with development of a racial identity. Her premise is that racial identity for whites is about their perceptions, feelings, and behaviors toward blacks rather than about the development and consciousness of an actual white racial identity.

The Cross, Parham, and Helms racial identity models all discuss what we would describe as an intersection between racial perceptions of others (racism) and racial perception of self (racial development). Although our perceptions of others are important and act as triggers for development and consciousness, there is great value in the consideration of racial and ethnic identity for oneself and groups of individuals.

Ethnic Identity Development. These models focus on what people learn about their culture from family and community. In other words, a sense of ethnic identity is developed from shared culture, religion, geography, and language of individuals who are often connected by strong loyalty and kinship as well as proximity (Torres, 1996). Aspects that make up learned culture include rituals, symbols, and behavior that manifest themselves from underlying values, beliefs, and assumptions (Ott, 1989). Models of identity development typically outline commonalities that are likely within a particular ethnic group. We discuss three of these models as representative of this concept. 
Garrett and Walking Stick Garrett (1994) provide a descriptive model of Native American identity and worldview. They offer numerous components of Native American ethnic values and perspectives, including the meaning of tribe, spirituality, harmony, balance, and humor. For example, Native Americans who hold strong cultural identification are likely to honor and use elders as resources in their negotiation of life's path. Ideally, within many Native American tribes individuals gain rather than decline in usefulness to the community as they age and develop a complex wisdom to be shared with members of the tribe. Garrett and Walking Stick Garrett's model is helpful in providing some sense of common patterns of Native American values, identity, and worldview. In addition, they contrast each Native component with "mainstream" culture, discuss the conscious nature of Native identity developed through cultural immersion, and provide some implications for working with Native American clients. It is important to note, however, that there can be enormous diversity within any ethnic population, so any model can serve only as a guide to common patterns of ethnic identity.

In her descriptive model of white ethnic identity and worldview, Katz (1989) identifies fifteen separate values and perspectives of white American cultural identity. These range from a concept of time, which is linear and guarded as a commodity, to a win-lose orientation, which is linked directly to the value of competition. Individuals within white, U.S. ethnic groups also tend to value and reward independence and autonomy. Katz points out that individuals who hold these beliefs "obscure" their connection to others and to a shared culture. Katz's model, although not empirically based, offers a more proactive frame than other models, as it is less constructed from a "whites are born racist" framework. This model does not, however, provide a developmental perspective outlining the journey whites experience in forming an ethnic identity. In addition, the Katz model does not address triggers (or their absence) for the development of consciousness of ethnic identity.

Phinney (1990) developed a model describing an ethnic identity process that she considers applicable to all ethnic groups. Phinney proposes that most ethnic groups must resolve two basic conflicts that occur as a result of their membership in a nondominant group. First, nondominant group members must resolve the stereotyping and prejudicial treatment of the dominant white population toward nondominant group individuals, thus bringing about a threat to their self-concept. Second, most ethnic minorities must resolve the clash of value systems between nondominant and dominant groups and the manner in which minority members negotiate a bicultural value system. Phinney's model is helpful in identifying very real triggers for consciousness and in outlining threats to ethnic selfconcept. However, it is still missing a discussion of the critical and positive aspect of immersion into one's own culture.

We believe that the resolution of the two issues we outlined may depend on the strength of the individual's cultural experience. Our own experience illustrates this. Alicia, who is Hispano and Native American 
(Mestiza), was raised both connected to and in her ancestral home in northern New Mexico. The village of Taos is isolated enough that individuals from these ethnic groups hold most educational, governmental, and business positions in the community. In addition, time, relationships, and other daily aspects of culture are primarily normed on a combined Native American and Hispano culture. For Alicia, this meant that even with many childhood years spent away from Taos, cultural messages within her community were consistent in providing positive, cultural role modeling. Brief time periods in other states with their educational and neighborhood communities also provided more than enough negative treatment for an understanding of the low value placed by many in the United States on these two cultures. These forays also provided triggers in her consciousness of ethnic identity and personal sense of otherness (Chávez, 1998).

Florence resolved her issue of ethnic identity by planting one foot firmly in the Italian culture and through her mama's well-intended pressure, used the other foot "to climb the social ladder out of Italianess" and "rise" to the standards of the dominant culture. Flo's youth was a daily celebration of the intertwined customs, symbols, and rituals of Catholicism, Southern Italians, and South Texans (both German and Mexican American). Often these cultural influences were punctuated by stark contrasts. For example, the Italian Catholic attended Mass every Sunday, helped Grandma Guido roll meatballs for lasagna, and stomped grapes with Grampa Guido for red table wine. At the same time, the German (white-dominant) influence of the South Texan culture led mama to encourage her daughter to stop dating her Mexican boyfriend and join the Cotillion and later the Junior League. Living these contrasts of Italian, German, and Mexican American cultures triggered in Flo a consciousness of ethnic identity and an ability to move in and out of both worlds.

\section{Implications for Adult Learning}

It is critical to understand the culturally constructed nature of educational environments and to develop an awareness of the effect of our own racially and ethnically defined sense of self, of learning, and of education. Difficulties arise for many minority and international adult learners when they attempt to negotiate learning environments that have been constructed within an ethnic base of values, behaviors, beliefs, and ways of doing things that is different from their own. Unfortunately, these racial and ethnic manifestations in the learning process are usually unconsciously applied by educators and peers, making them difficult to identify, examine, and modify. For this reason it is important for educators to make "the invisible visible" in their learning environments and in their own roles as educators. This allows educators to then develop multicultural practices.

We believe that learning environments must first be inclusive of multicultural ways of doing, bases of knowledge, perspectives, and styles of edu- 
cating. Second, a strong learning community must be created that honors, supports, and challenges each learner to be a uniquely contributing member.

Racial and ethnic identity can affect the relationship with learning that individuals have in their learning environments. Most individuals from white ethnic groups have experienced learning that is grounded in their own cultural norms. These individuals have not typically learned multiculturally and are likely to struggle in multicultural educational environments. In addition, their communal skills may be less well developed. Persons from other groups and some white ethnic individuals have experienced learning that is grounded outside their own cultural norms and have learned to some extent to negotiate multiple cultural environments. However, they may continue to struggle even after many years of white-normed education.

Educators can benefit all types of learners by creating environments that balance different cultural norms, such as by designing collaborative and individual tasks, encouraging reflective and discussion activities, and using visual, written, relational, and other types of learning styles (Gardner, 1997). Curricula and activities must be consciously and visibly multicultural to include a variety of worldviews and bases of knowledge. In addition, educators must continually reflect on the influence of the relationship between their own racial and ethnic identity and how they define an effective learning environment and a successful learner. Feelings of comfort and "rightness" for many educators are likely to mean that they have created a learning environment based on their own cultural norms rather than on a multicultural learning framework.

Both racial and ethnic identity affect the experience with and interpretation of relationships with others in the learning environment. As a result of their racial and ethnic identities, learners bring to the learning environment vastly different experiences of treatment by teachers and peers. Members of many minority and international groups bring an experience of consciously having to negotiate and even survive educational treatment of invisibility or negative ultravisibility, lowered expectations, stereotyping, hostility, and even abuse (Vontress, 1996). Many of these individuals have learned despite their learning environments rather than because of them. These individuals' bicultural or multicultural experience of life makes it likely that they will possess some level of multicultural skills, an enhanced ability to compare and contrast multiple perspectives, and keen reflective and observational abilities. To cope with others' racial and ethnic reactions to them, however, they may react cautiously, assertively, or sometimes aggressively to teachers and peers. These learners often have a "radar" for sincerity in others' treatment of them that carries into learning environments. Most white individuals, in contrast, are likely to experience and be resistant to ways of learning and doing that are outside the educational norms in which they have been raised. These learners are likely to lack multicultural and self-reflective skills; they are likely to insist on individual tasks and rewards and to discount knowledge bases that seem "alternative." 
Educators can create positive multicultural learning communities by teaching in authentic, relational, and self-sharing ways, by encouraging and offering nonjudgmental processing of multiple perspectives, and by facilitating a sense of respectful community within the learning environment. In addition, educators can help learners understand the benefits of developing multicultural understandings and skills for future work and community environments. Attention to these concerns of racial and ethnic identity will greatly enhance the learning experience for everyone.

\section{References}

Chávez, A. F. "Weaving My Way: The Cultural Construction of Writing in Higher Education." Journal of Poverty, 1998, 2 (4), 89-93.

Chávez, A. F., Guido-DiBrito, F., and Mallory, S. "Learning to Value the 'Other': A Model of Diversity Development." Paper presented at the National Association of Personnel Administrators Conference, Atlanta, Mar. 1996.

Cross, W. E., Jr. "Toward a Psychology of Black Liberation: The Negro-to-Black Convergence Experience." Black World, 1971, 20 (9), 13-27.

Cross, W. E., Jr. "The Psychology of Nigrescence: Revising the Cross Model." In J. G. Ponterott, J. M. Casas, L. A. Suzuki, and C. M. Alexander (eds.), Handbook of Multicultural Counseling. Thousand Oaks, Calif.: Sage, 1995.

Erikson, E. Identity and the Life Cycle. New York: Norton, 1959/1980.

Evans, N. J., Forney, D. S., and Guido-DiBrito, F. Student Development in College: Theory, Research and Application. San Francisco: Jossey-Bass, 1998.

Garrett, J. T., and Walking Stick Garrett, M. "The Path of Good Medicine: Understanding and Counseling Native American Indians." Journal of Multicultural Counseling and Development, 1994, 22, 134-144.

Gardner, H. Extraordinary Minds: Portraits of Exceptional Individuals and Examination of Our Extraordinariness. New York: Basic Books, 1997.

Harris, H. W. "Introduction: A Conceptual Overview of Race, Ethnicity and Identity." In H. W. Harris, H. C. Blue, and E.E.H. Griffith (eds.), Racial and Ethnic Identity: Psychological Development and Creative Expression. New York: Routledge, 1995.

Helms, J. E. "Introduction: Review of Racial Identity Terminology." In J. E. Helms (ed.), Black and White Racial Identity: Theory, Research and Practice. Westport, Conn.: Praeger, 1993.

Helms, J. E. "The Conceptualization of Ethnic Identity and Other 'Racial' Constructs." In E. J. Thicket, R. J. Watts, and D. Birman (eds.), Human Diversity: Perspectives on People in Context. San Francisco: Jossey-Bass, 1994.

Helms, J. E. "An Update of Helms' White and People of Color Racial Identity Models." In J. G. Ponterott, J. M. Casas, L. A. Suzuki, and C. M. Alexander (ed.), Handbook of Multicultural Counseling. Thousand Oaks, Calif.: Sage, 1995.

Katz, J. H. "The Challenge of Diversity." In C. Woolbright (ed.), College Unions at Work, Monograph No. 11, 1-17. Bloomington, Ind.: Association of College UnionsInternational, 1989.

Littlefield, A., Lieberman, L., and Reynolds, L. T. "Redefining Race: The Potential Demise of a Concept in Anthropology." Current Anthropology, 1982, 23, 641-647.

Marcia, J. E. "Identity in Adolescence." In J. Adelson (ed.), Handbook of Adolescent Psychology. New York: Wiley, 1980.

O'Hearn, C. C. Half and Half: Writers Growing Up Biracial and Bicultural. New York: Pantheon Books, 1998.

Ott, S. The Organizational Culture Perspective. Chicago: The Dorsey Press, 1989.

Parham, T. "Cycles of Psychological Nigrescence." The Counseling Psychologist, 1989, 17 (2), 187-226. 
Phinney, J. S. "Ethnic Identity in Adolescents and Adults: Review of the Research." Psychological Bulletin, 1990, 108, 499-514.

Piaget, J. The Origins of Intelligence in Children. New York: International Universities Press, 1952.

Spickard, P. R. "The Illogic of American Racial Categories." In M.P.P. Root (ed.), Racially Mixed People in America. Thousand Oaks, Calif.: Sage, 1992.

Torres, V. Empirical Studies in Latino/Latina Ethnic Identity. Paper presented at the National Association of Student Personnel Administrators National Conference, Baltimore, Mar. 1996.

Vontress, C. "A Personal Retrospective on Cross Cultural Counseling." Journal of Multicultural Counseling and Development, 1996, 24, 156-166.

Waters, M. C. Ethnic Options: Choosing Identities in America. Berkeley, Calif.: University of California Press, 1990.

Yinger, J. M. "Ethnicity in Complex Societies." In L. A. Coser and O. N. Larsen (eds.), The Uses of Controversy in Sociology. New York: Free Press, 1976.

ALICIA FEDELINA CHÁVEZ is an assistant professor in the Department of Educational Leadership at Miami University in Oxford, Ohio.

FLORENCE GUIDO-DIBRITO is associate professor in the Department of Educational Leadership at the University of Northern Colorado, Greeley. 
